\title{
ARBUSCULAR MYCORRHIZAL FUNGI AND DARK SEPTATE ENDOPHYTIC FUNGI ON THE BIOMASS DEVELOPMENT OF VETIVER GRASS ${ }^{1}$
}

\author{
JESSICA SILVA SANTOS ${ }^{2}$, JACILENE FRANCISCA SOUZA SANTOS ${ }^{2}$, LÁZARA JOSSIKARLA DE OLIVEIRA \\ LOPES $^{2}$, JOHNY DE JESUS MENDONÇA ${ }^{2}$, FRANCISCO SANDRO RODRIGUES HOLANDA ${ }^{2}$, REGINA HELENA \\ MARINO $^{2 *}$
}

\begin{abstract}
Vetiver grass is a member of the grass family Poaceae. Its fast development is probably due to the interaction with native microbiota, whose influence has not been studied yet. The objective of this work was to evaluate the colonization and development of the vetiver grass (Chrysopogon zizanioides (L.) Roberty) inoculated with arbuscular mycorrhizal fungi and dark septate endophytic fungi. The experimental design was a completely randomized design with six treatments (control, without mycorrhizal fungi, native inoculants, UFLA05 - Gigaspora albida, UFLA351 - Rhizoglomus clarum, UFLA372 - Claroideoglomus etunicatum, and UFLA401 - Acaulospora morrowiae), with three replicates each. Vetiver grass tillers as well as the native microbial inoculum were obtained from the Lower São Francisco river experimental area, located in Sergipe state, Northeastern Brazil. There was a negative interaction between all tested UFLAs mycorrhizal isolates and the native microbiota (mycorrhizal and endophytic fungi) in the treatments, especially when taking into consideration plant height and volume of roots. The effects of inoculation with UFLA isolates may have been influenced by the presence of the native mycorrhizal fungi and the dark septate endophytic fungi. Vetiver grass was responsive to the native inoculant. The mycorrhizal colonization of the vetiver grass was vesicular, but the formation of the arbuscules can be influenced by the interaction between the fungus, plant, and the environment.
\end{abstract}

Keywords: Poaceae. Chrysopogon zizanioides. Filamentous fungi.

\section{FUNGOS MICORRÍZICOS ARBUSCULARES E ENDOFÍTIOS “DARK SEPTATE" NO DESENVOLVIMENTO DA BIOMASSA DO CAPIM VETIVER}

\begin{abstract}
RESUMO - O capim vetiver é uma espécie da família poácea que apresenta rápido desenvolvimento, provavelmente decorrente da interação com a microbiota nativa, cuja influência ainda não foi estudada. $O$ objetivo deste trabalho foi avaliar a colonização e o desenvolvimento do capim vetiver inoculado com fungos micorrízicos arbusculares e fungos endofíticos "dark septate". O delineamento experimental utilizado foi inteiramente casualizado composto por seis tratamentos (controle sem fungo micorrízico; inoculante microbiano nativo; UFLA05 - Gigaspora albida, UFLA351 - Rhizoglomus clarum, UFLA372 Claroideoglomus etunicatum e UFLA401 - Acaulospora morrowiae), com três repetições. Os perfilhos de capim vetiver, assim como o inóculo microbiano nativo foram obtidos na área experimental do Baixo São Francisco, localizado no Estado de Sergipe, Nordeste do Brasil. O efeito da inoculação dos isolados UFLAs pode ter sido influenciado pela presença da micorriza nativa e pelos fungos endofíticos "dark septate". Houve uma interação negativa entre todos isolados UFLAs testados e a microbiota nativa (micorriza e endofítico), nos tratamentos, principalmente quando se considera a altura da planta e o volume de raízes. O capim vetiver foi responsivo ao inoculante microbiano nativo. A colonização micorrízica do capim vetiver foi vesicular, mas a formação dos arbúsculos pode ser influenciada pela interação fungo, planta e ambiente.
\end{abstract}

Palavras-chave: Poaceae. Chrysopogon zizanioides. Fungos filamentosos.

\footnotetext{
${ }^{*}$ Corresponding author

${ }^{1}$ Received for publication in $01 / 05 / 2017$; accepted in 10/18/2017.

Paper extracted from the scientific initiation work of the first author.

${ }^{2}$ Department of Agronomic Engineering, Universidade Federal de Sergipe, São Cristóvão, SE, Brazil; jsksantos1991@gmail.com ORCID: 0000-0001-8789-0146, jacilenesantos_14@hotmail.com - ORCID: 0000-0001-5109-3663, lazaralopesagro@gmail.com ORCID: 0000-0002-2413-0016, mendonca.johny@yahoo.com.br - ORCID: 0000-0002-7690-6234, fholanda@infonet.com.br - ORCID: 0000-0001-6812-6679, rehmarino@hotmail.com - ORCID: 0000-0002-7295-3746.
} 


\section{INTRODUCTION}

Vetiver grass (Chrysopogon zizanioides (L.) Roberty) is a member of the family Poaceae, native to India, which is resistant to pests and diseases and is tolerant to climatic variations, probably due to efficient absorption of nutrients such as nitrogen and phosphorus (TRUONG; VAN; PINNERS, 2008). The abundant root system of vetiver grass, due to the significant shear strength of its fine roots (MACHADO et al, 2015), contributes to the formation of soil aggregates, which are important in slope stabilization (BARBOSA; LIMA, 2013). This grass is also used in the recovery of soils that are contaminated by lead, since it presents tolerance to, and efficiency in the absorption, accumulation, and translocation of this heavy metal to the aerial part (ALVES et al., 2008).

One of the ways to increase plant survival under adverse conditions may be through association with growth promoting fungi, such as mycorrhizal fungi (MIRANDA, 2008). Among these, the arbuscular mycorrhizal fungi, belonging to the phylum Glomeromycota, have a symbiotic association with more than $86 \%$ of the known plants, the association being an obligatory biotrophic interaction occurring in several ecosystems (MOREIRA; SIQUEIRA, 2006).

The symbiotic relationship between the arbuscular mycorrhizal fungi and the plants may favor vegetative development in the plants. This could be due to the greater area of contact with the soil as a result of the fungal hyphae, allowing more efficient water and nutrient absorption, or by the stimulating action of the fungi on root growth (VAN DER HEIJDEN et al., 2015). These authors also state that the symbiotic association with mycorrhizal fungi can increase the phosphorus content in plants by over $90 \%$ through the action of the mycelium, which acts as a reserve of this element in the soil, mainly in natural low fertility environment. Arbuscular mycorrhizal fungi may also contribute to the formation of fine roots and the release of glomalin, a protein substance responsible for aggregation of soil particles, which reduces soil losses due to erosion (SOUSA et al., 2012).

The symbiotic association of the vetiver grass with the mycorrhizal fungi belonging to the genus Glomus was described by Caporale et al. (2014) in soils contaminated with arsenic. Similarly, Karimi, Baharlouei and Sabzalian (2014) evaluated the effect of the mycorrhizal fungi Glomus mosseae in the vetiver grass growing in cadmium-contaminated soils. However, there are no reports on the association of vegetative and reproductive development of vetiver grass with arbuscular mycorrhizal isolates. The objective of this work was to evaluate the colonization and development of the vetiver grass (Chrysopogon zizanioides (L.) Roberty) inoculated with arbuscular mycorrhizal fungi and dark septate endophytic fungi.

\section{MATERIAL AND METHODS}

A completely randomized experimental design was used, consisting of six treatments (Control - without mycorrhizal fungi, native microbial inoculant, and four mycorrhizal isolates: UFLA05 - Gigaspora albida Schenck \& Smith, UFLA351 - Rhizoglomus clarum (Nicolson \& Schenck) Sieverd, Silva \& Oehl, UFLA372 - Claroideoglomus etunicatum (Becker \& Gerd.) Walker \& Schüßer, and UFLA401 - Acaulospora morrowiae Spain \& Schenck), each with three replicates.

Production of mycorrhizal inoculant

The native microbial inoculum was collected from the collected from the soil's rhizosphere of vetiver grass plants grown in the experimental area of a project studying soil bioengineering techniques for erosion control in the slopes of the right bank of the lower São Francisco River, in the municipality of Amparo de São Francisco (coordinates: UTM 744.301.092E and 8868.461.918 N), in Sergipe state, Northeastern Brazil. The soil in the collection area was classified as Fluvic Neosol, composed of more than $90 \%$ fine and very fine sand (HOLANDA et al., 2010). The UFLA isolates were donated by the Laboratory of Soil Microbiology, from Universidade Federal de Lavras.

The mycorrhizal inoculant (both native and UFLAs isolates) were cultured in vessels using a substrate made of autoclaved sandy soil and mycorrhizal inoculum in the ratio $2: 1$. The inoculant was distributed between two layers of sandy soil, after which sorghum seeds were sown. These cultures were incubated in an agricultural greenhouse for 60 days. In order to stimulate mycorrhizal sporulation, the shoots were harvested from sorghum and the irrigation was suspended for 15 days.

\section{Collection and multiplication of vetiver tillers}

Vetiver grass tillers were also collected in the experimental area located in the Lower São Francisco River, and multiplied in a substrate of autoclaved sandy soil, supplemented by $800 \mathrm{mg} \mathrm{dm}^{-3} \mathrm{P}_{2} \mathrm{O}_{5}$ using a phosphate water soluble fertilizer that was based on rock dust with $18 \% \mathrm{P}_{2} \mathrm{O}_{5}$. A high concentration of phosphate fertilizer was used in order to inhibit mycorrhization by native mycorrhizal fungi. The incubation was carried out in an agricultural greenhouse with irrigation for 70 days. After this period, root fragments were collected and mycorrhizal colonization and percentage of hyphae, vesicles, and arbuscules were 
evaluated, according to Giovannetti and Mosse (1980) with modifications. For this purpose, the root fragments were analyzed with gridded slides under an optical microscope.

Bioassay for evaluation of microbial interaction on vetiver grass growth

A substrate made of autoclaved sandy soil and commercial coconut powder (Cocos nucifera L.) was taken in a ratio of $2: 1$. The substrate mixture was packed in plastic bags with a capacity of three kilograms and then $50 \mathrm{~g}$ of mycorrhizal inoculant composed of the mixture of sandy soil, root fragments of the sorghum plant, and mycorrhizal structures (hyphae, vesicles, and spores) was added. In the inoculant of the isolates UFLA05, UFLA351, UFLA372, and UFLA401, the spore numbers were, on average, 20 spores per $50 \mathrm{~g}$ of sandy soil. For the native microbial inoculant, the mean number of arbuscular mycorrhizal fungi spores was 30 spores per $50 \mathrm{~g}$ of sandy soil. After the inoculation, a tiller of $15 \mathrm{~cm}$ height was transplanted to a plastic bag and incubated in an agricultural greenhouse. Fertilization was performed 30 days after inoculation and was weekly repeated. A total of $3 \mathrm{~mL}$ of the solution was used, which was prepared with $10 \mathrm{~g} \mathrm{~L}^{-1}$ of the fertilizer composed by $13 \%$ total nitrogen, $5 \%$ phosphorus, $13 \%$ potassium, $5 \%$ sulfur, $1 \%$ calcium, $1 \%$ magnesium, $2 \%$ iron, $0.15 \%$ zinc, $0.08 \%$ manganese, $0.04 \%$ boron, $0.05 \%$ copper, and $0.005 \%$ molybdenum.

After 100 days of tillers transplanting and incubation, the evaluated parameters were: plant height $(\mathrm{cm})$, root length $(\mathrm{cm})$, shoot and root dry matter (g), mycorrhizal colonization (\%), number of spores of mycorrhizal isolates, mycorrhizal dependence $(\%)$, root colonization by dark septate endophytic fungi (\%), presence of endophytic fungi on the leaves, and the number of tillers. Plant height and root length were evaluated using a millimeter ruler, whose measurements were taken from the lap of the plant. The shoot and root dry matter were determined using a semi-analytical balance and drying at $60{ }^{\circ} \mathrm{C}$ for three days.

Mycorrhizal dependence (MD) was evaluated using data on the dry matter content of shoot, root dry matter, and root length, in relation to the control using the equation 1 : $\operatorname{MD}(\%)=([(\mathrm{MP}-\mathrm{CP})) / \mathrm{MP}] \times 100)$, where MP is the value in the plant inoculated with the mycorrhizal fungi and $\mathrm{CP}$ is the value in the control. The classification of mycorrhizal dependence was described by Machineski, Balota and Souza (2011), according to which plants that presented values $>75 \%$ were classified as excessively dependent; from 50 to $75 \%$ as highly dependent; 25 to $50 \%$ as moderately dependent, and $<25 \%$ as marginally dependent or does not respond to inoculation.
Mycorrhizal colonization (MC) and the percentage of hyphae, vesicles, and arbuscules were evaluated by the intersection method, following Giovannetti and Mosse (1980) with modifications. The root fragments were analyzed under an optical microscope, using gridded slides. The percentage of mycorrhizal colonization (MC) was calculated by equation 2: $\mathrm{MC}(\%)=((\mathrm{TNCF} / \mathrm{TNFA}) \times 100)$, where TNCF is the total number of colonized fragments, and TNFA is the total number of fragments analyzed (colonized and non-colonized).

The dark septate endophytic fungi (DSEND) present in the root fragments were identified by the presence of melanized and septate hyphae (RIBEIRO et al., 2011). The percentage of dark septate endophytic fungi was determined by equation 3 : DSEND $(\%)=(($ NEND / TNF $) \times 100)$, where NEND is the number of endophytes, and TNF is the total number of root fragments analyzed.

Endophytic fungi were isolated from the leaf fragments $\left(0.5 \mathrm{~cm}^{2}\right)$ after immersing these in $70 \%$ alcohol for 1 minute, followed by sodium hypochlorite $0.2 \%$, and triple washed in distilled water that was autoclaved for 1 minute. Leaf fragments were transferred to potato-dextrose-agar (PDA) culture medium containing streptomycin sulfate ( 0 to $0.01 \mathrm{~g} \mathrm{~L}^{-1}$ of medium) and incubated at $25 \pm 1{ }^{\circ} \mathrm{C}$, without photoperiod, for three days. The identification of the observed fungi was based on the hyphae and on the fruiting bodies under the optical microscope using a magnification of up to 100 times.

The number of spores of the mycorrhizal isolates that were tested was quantified in $50 \mathrm{~g}$ of vetiver grass culture substrate using the wet sieving method, according to the methodology of Gerdemann and Nicolson (1963). The number of tillers was obtained by direct counting, per plant.

The data were submitted to analysis of variance (ANOVA), and in cases where there was a significant difference, the Scott-Knott test was applied at a $5 \%$ significance level to compare the means. The mycorrhizal colonization data were transformed by $\arcsin (\mathrm{x})$. Correlations and statistical analyzes were performed using the software Assistat version 7.7 .

\section{RESULTS AND DISCUSSION}

The collected tillers in the field to use to multiplicate the vetiver grass presented $56.6 \%$ of mycorrhizal colonization, characterized by vesicles (62.2\%), hyphae $(23.1 \%)$, spores associated with root fragments $(9.8 \%)$, and arbuscules $(4.9 \%)$. According to Carneiro et al. (1998), the mycorrhizal colonization of field tillers was high, which may influence the biomass and root formation of this grass. This is similar what was reported by Barbosa and Lima (2013), Caporale et al. (2014), and Machado et al. (2015) for other species of the family 
Poaceae.

The symbiotic association between vetiver grass and arbuscular mycorrhizal fungi was earlier described only for Glomus intraradices, G. mosseae, and $G$. aggregatum in studies on bioremediation of contaminated soils (KARIMI; BAHARLOUEI; SABZALIAN, 2014; CAPORALE et al., 2014). However, these studies did not report the percentages of colonization.

In relation to other Poaceae members, Ramos et al. (2012) have reported that the mycorrhizal colonization in Panicum maximum 'Aruana' was $51.2 \%$ and in Brachiaria humidicola it was $60.4 \%$. Rubin and Stürmer (2015) have mentioned that the mycorrhizal colonization of Brachiaria brizantha varied from 13.8 to $55.3 \%$, a sufficient level to guarantee the growth of plants in degraded areas. Machado et al. (2015) also observed the rapid development of the vetiver grass, which may have been due to the high observed colonization in the tillers collected in the field.

The cultivation of tillers colonized by native mycorrhizal fungi, cultivated with $800 \mathrm{mg} \cdot \mathrm{dm}^{-3}$ of the $\mathrm{P}_{2} \mathrm{O}_{5}$, reduced mycorrhizal colonization from $56.6 \%$, observed in the tillers collected from the field, to $10.2 \%$. In this context, Moreira, Barretta and Cardoso (2012) observed that increasing phosphorus content up to $150 \mathrm{mg} \mathrm{kg}^{-1}$ a decrease of Scutellospora gilmorei and Glomus etunicatum sporulation was observed, and high phosphorus stimulated sporulation of Acaulospora. Similarly, in our study, the application of phosphorus fertilizers in high dosages may have influenced colonization of tillers with high phosphorus dosage, in the control, and in the treatments with the UFLAs isolates.

Following Graham et al. (1982) report that the low percentage of mycorrhizal colonization may present high mycorrhizal efficiency, i.e., the lower colonization may positively influence the vegetative development of the host plant; our observation of low colonization $(10.2 \%)$ of the vetiver grass tiller used in the bioassay should not be disregarded. In addition, the mycorrhizal colonization of the tillers with the native arbuscular mycorrhizal fungi community may influence the action of the UFLA isolates on the vetiver grass.

After 100 days of cultivation, vetiver grass inoculated with UFLA05, UFLA372, UFLA401, and native mycorrhizal fungi showed a mycorrhizal colonization of 11.9 to $21.1 \%$, being significantly superior to the control (4.1\%) and UFLA351, which showed $1 \%$ colonization (Table 1$)$.

Table 1. Percentage of mycorrhizal colonization (MC), hyphae (H), vesicles (V), spores (SP), and dark septate endophyte fungi (DSEND) observed in vetiver grass cultivated with native microbial inoculant and arbuscular mycorrhizal fungi, 100 days after inoculation.

\begin{tabular}{lccccr}
\hline Treatments $^{1}$ & $\mathrm{MC}(\%)$ & $\mathrm{H}(\%)$ & $\mathrm{V}(\%)$ & SP $(\%)$ & DSEND (\%) \\
\hline Control & $4.1 \pm 1.4 \mathrm{~b}^{2}$ & $0.0 \pm 0.0 \mathrm{a}$ & $100.0 \pm 0.0 \mathrm{a}$ & $0.0 \pm 0.0 \mathrm{a}$ & $8.8 \pm 11.7 \mathrm{a}$ \\
Native & $21.1 \pm 1.7 \mathrm{a}$ & $20.8 \pm 19.1 \mathrm{a}$ & $79.2 \pm 19.1 \mathrm{a}$ & $8.3 \pm 22.4 \mathrm{a}$ & $16.6 \pm 19.5 \mathrm{a}$ \\
UFLA05 & $11.9 \pm 17.8 \mathrm{a}$ & $4.2 \pm 7.2 \mathrm{a}$ & $58.3 \pm 52.0 \mathrm{a}$ & $4.2 \pm 7.2 \mathrm{a}$ & $6.5 \pm 9.3 \mathrm{a}$ \\
UFLA351 & $1.0 \pm 1.7 \mathrm{~b}$ & $0.0 \pm 0.0 \mathrm{a}$ & $0.0 \pm 0.0 \mathrm{a}$ & $33.3 \pm 57.7 \mathrm{a}$ & $15.2 \pm 13.8 \mathrm{a}$ \\
UFLA372 & $15.9 \pm 6.5 \mathrm{a}$ & $3.0 \pm 5.3 \mathrm{a}$ & $63.3 \pm 55.3 \mathrm{a}$ & $0.0 \pm 0.0 \mathrm{a}$ & $15.0 \pm 16.7 \mathrm{a}$ \\
UFLA401 & $12.3 \pm 0.7 \mathrm{a}$ & $4.8 \pm 8.3 \mathrm{a}$ & $41.7 \pm 25.8 \mathrm{a}$ & $53.6 \pm 34.1 \mathrm{a}$ & $8.3 \pm 13.1 \mathrm{a}$ \\
\hline
\end{tabular}

${ }^{1}$ Treatments: Control - without inoculation with arbuscular mycorrhizal fungi; Native-native microbial inoculant; UFLA05 - G. albida; UFLA351 - R. clarum; UFLA372 - C. etunicatum; UFLA401 - A. morrowiae; and $^{2}$ Averages followed by the same letter in the column do not differ statistically from each other at $5 \%$ probability by the Scott-Knott test.

In the control, the mycorrhizal colonization of vetiver grass $(4.1 \%)$ was characterized by the presence of vesicles $(100.0 \%)$, but without the presence of hyphae and spores associated with the root (Table 1). It should be noted that this colonization occurred from the native mycorrhizal fungi already present in the tillers used in the bioassay, since the use of high phosphorus dosage did not eliminate these microorganisms, but only reduced the colonization.

The use of the native microbial inoculants resulted in the mycorrhizal colonization of vetiver grass $(21.1 \%)$ characterized by the presence of hyphae $(20.8 \%)$, vesicles $(79.2 \%)$, and spores in the root fragments that were analyzed $(8.3 \%$, Table 1$)$. This was lower than the $56.6 \%$ colonization of field vetiver grass. This result may be due to the reduction of mycorrhizal species pretty much related to vetiver grass by the use of high phosphorus dosage in the multiplication phase of the tillers. In addition, infective propagules (30 spores of the native mycorrhizal fungi community in $50 \mathrm{~g}$ of sandy soil) were added to this treatment, which may have contributed to a significant increase in the colonization of the vetiver grass in the treatment with native microbial inoculum (21.1\%) when compared to the control, without addition of any inoculant (Table 1).

The vetiver grass inoculated with UFLA05 presented $11.9 \%$ mycorrhizal colonization characterized by hyphae $(4.2 \%)$, vesicles $(58.3 \%)$, and spores $(4.2 \%)$ associated with root fragments. However, UFLA351 resulted in $1.0 \%$ colonization characterized only by spores $(33.3 \%)$. In the UFLA372, the colonization was $15.9 \%$, which was characterized by hyphae $(3.0 \%)$ and vesicles 
(63.3\%). Further, vetiver grass inoculated with UFLA401 presented colonization of $12.3 \%$ and was characterized by hyphae (4.8\%), vesicles $(41.7 \%)$, and spores $(53.6 \%)$ (Table 1$)$.

Stürmer and Siqueira (2008) mention that with the genus Gigaspora such as the isolate UFLA05, vesicles are not formed, which is the typical structure for the families Acaulosporaceae (Acaulospora sp.) and Glomeraceae (Glomus sp. and Paraglomus sp.). Thus, the presence of vesicles in the UFLA05 may be correlated with colonization of the tiller by native mycorrhizal fungi, with a high percentage of vesicles, under field conditions and/or by contamination with the isolates $C$. etunicatum (UFLA372) or A. morrowiae (UFLA401). R. clarum (UFLA351), did not show presence of vesicles (Table 1). The presence of vesicles in Poaceae may favor the survival of the mycorrhizal isolate under adverse field conditions, because this is a reserve structure of lipids and mycorrhizal propagules (LOPES; SIQUEIRA; ZAMBOLIM, 1983).

In the evaluation of mycorrhizal colonization, appressoria and arbuscules, two important fungal structures in the fungi-plant symbiosis, were not observed (MOREIRA; SIQUEIRA, 2006; STÜRMER; SIQUEIRA, 2008). Santos et al. (2013) also mentioned that in the mycorrhizal colonization of the grasses Panicum maximum, Paspalum conspersum, and Sorghum arundinaceum, arbuscules were not observed. However, in the evaluation of the mycorrhizal colonization of the tillers of the vetiver grass collected in the field, the arbuscules were observed. García and Mendonza (2008) have reported that the mycorrhizal colonization of Paspalum vaginatum was arbuscular in the spring, whereas in the summer it was vesicular. This could have occurred with the vetiver grass in this experiment as well, since it was conducted during the spring/summer period (October/January) when a high percentage of vesicles was observed, while the analysis of the collected tillers, from the field in the Brazilian Northeast region was carried out during the rainy season (June).

In addition to the mycorrhizal colonization of vetiver grass, septate and melanized hyphae, which characterize the presence of the dark septate endophytic fungi, were observed in $6.5 \%$ to $16.6 \%$ of the root fragments analyzed, with no statistical difference between the treatments (Table 1) (RIBEIRO et al., 2011). Santos et al. (2013) reported the absence of dark septate endophytic fungi in Panicum maximum, Paspalum conspersum, and
Sorghum arundinaceum, which may be related to the strong relationship between the endophytic fungi and the plant species and not with the botanical family.

Santos and Varavallo (2011) note that depending on the fungi-plant relationship, dark septate endophytic fungi, may contribute to the survival of plant species under adverse conditions. Thus, the presence of these microorganisms can mask the effects of the isolates (UFLAs), since they can promote the vegetative growth of the plant or can present antifungal, antibacterial, and insecticidal properties (YAN et al., 2015).

In the leaf analysis of the vetiver grass, the fungi Nigrospora and Rhizoctonia were observed, without causing damage to the vegetal tissue. The genus Nigrospora can be considered as dark septate endophytic fungi, capable of controlling phytopathogenic agents such as Fusarium, a genus of fungi that causes root rot and degradation xylem vessels according to a review by Dutta et al. (2014). In the evaluation of mycorrhizal colonization of the root fragments of the vetiver grass it was not possible to find if the dark septate fungi observed belongs to the genus Nigrospora, because at this stage, structures used for taxonomic identification were not observed.

In relation to the number of spores in the substrate of the cultivar, native mycorrhizal fungi, UFLA05, and UFLA351 showed higher sporulation, compared to UFLA372 and UFLA401 (Figure 1). This difference in sporulation among mycorrhizal treatments may be due to fungi-plant compatibility. According to Moreira and Siqueira (2006), host plants may produce bioactive compounds, which may inhibit or stimulate mycorrhization and, consequently, mycorrhizal spore production. In addition, it should be considered that in all treatments, even in the control, the sandy soil used as substrate was autoclaved, what may have eliminated all spores the arbuscular mycorrhizal fungi from the soil, but the tiller used in the bioassay were colonized even after the addition of phosphorus based fertilizers, which may have contributed to the sporulation of native mycorrhizal fungi in this treatment.

In the control and treatments with native microbial inoculant, the number of spores was negatively correlated with mycorrhizal colonization (Table 2). This may be related to a way of preserving the native mycorrhizal species through the spores, as these may be viable for some months in the absence of the host plant (MOREIRA; SIQUEIRA, 2006). 


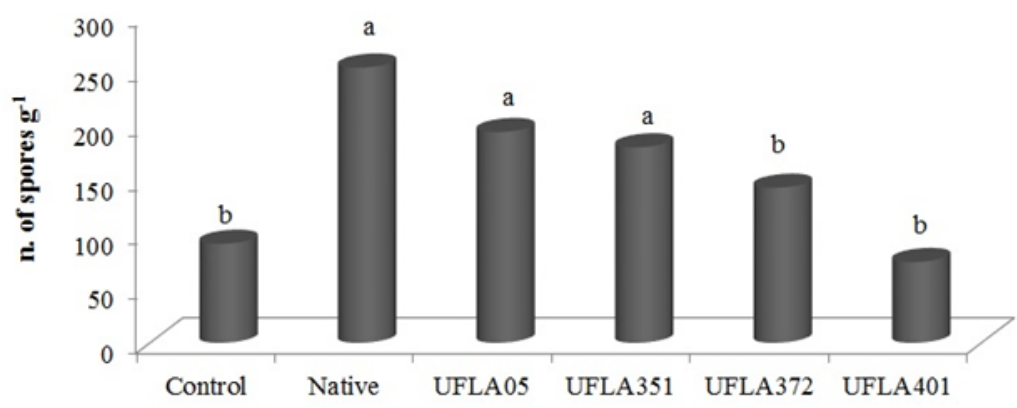

Figure 1. Number of spores of arbuscular mycorrhizal fungi ${ }^{1}$ obtained on the vetiver grass substrate that was cultivated with native microbial inoculants and UFLAS isolates after 100 days of the inoculation ${ }^{2}$.

${ }^{1}$ Treatment: Control - without inoculation with arbuscular mycorrhizal fungi; Native - native microbial inoculant; UFLA05 - G. albida; UFLA351 - R. clarum; UFLA372 -C. etunicatum; UFLA401 - A. morrowiae; and ${ }^{2}$ Averages followed by the same letter not differ statistically from each other a $5 \%$ probability by the Scott-Knott test.

Table 2. Correlation coefficient (r) between the parameters of mycorrhizal colonization (MC), dark septate endophytic fungi (DSEND), and number of spores (NE) obtained in vetiver grass cultivated with native microbial inoculant and UFLAs isolates.

\begin{tabular}{lccccc}
\hline Parameters & \multicolumn{5}{c}{ Correlation coefficient (r), by treatment $^{1}$} \\
\cline { 2 - 6 } & Control & Native & UFLA05 & UFLA 351 & UFLA 372 \\
\hline NE x MC & $-0.999 * *^{2}$ & $-0.998 * *$ & - & $0.988 *$ & - \\
NE x DSEND & - & - & - & $0.984 *$ & - \\
DSEND x CM & - & - & - & - & $0.998 * *$ \\
\hline
\end{tabular}

${ }^{1}$ Treatment: Control - without inoculation with arbuscular mycorrhizal fungi; Native - native microbial inoculant; UFLA05 - G. albida; UFLA351 - R. clarum; UFLA372 - C. etunicatum e UFLA401 - A. morrowiae; and ${ }^{2} \mathrm{~ns}=$ not significant; $*=$ significant at $5 \%$ probability $(0.1 \leq \mathrm{p}<0.5)$ and $* *=$ significant at $1 \%$ probability $(\mathrm{p}<0.1)$.

The number of spores obtained in the vetiver grass substrate with the isolates UFLA05 and UFLA401 was not correlated with mycorrhizal colonization and the presence of endophytic fungi. There was also no correlation between the dark septate endophytic fungi and mycorrhizal colonization (Table 2). Lima, Salcedo and Fraga (2007) also did not observe a relationship between spore density and colonization, which characterize that colonization and sporulation depend, among other factors, on the fungi-plant interaction. However, the number of spores of UFLA351 was positively correlated with mycorrhizal colonization and the presence of dark septate endophytic fungi, although there was no correlation between mycorrhizal colonization and the presence of dark septate endophytic fungi.

There was a positive correlation between the dark septate endophytic fungi and colonization by UFLA372, which characterizes a cooperative relationship, since endophytic fungi can stimulate soil microbiota activity, depending on the microbial interaction (YAN et al., 2015). This was also observed in the sporulation of UFLA351 (Table 2).

Vetiver grass in the control, native microbial inoculant, UFLA351, UFLA372, and UFLA401 treatments showed plants with plant height and shoot dry matter values significantly higher than the UFLA05 isolate. There was no significant difference in root length, although the native microbial inoculant favored the root dry matter, in relation to the other treatments (Table 3 ).

Table 3. Plant height (H), shoot dry matter (SDM), root length (RL), root dry matter (RDM), and number of tillers (NT) obtained in vetiver grass cultivated with arbuscular mycorrhizal fungi, after 100 days of inoculation.

\begin{tabular}{llcccc}
\hline \multicolumn{1}{c}{ Treatments $^{1}$} & $\mathrm{H}(\mathrm{cm})$ & SDM $(\mathrm{g})$ & RL $(\mathrm{cm})$ & RDM $(\mathrm{g})$ & NT \\
\hline Control & $92.4 \pm 6.6 \mathrm{a}$ & $2.3 \pm 0.6 \mathrm{a}$ & $32.3 \pm 3.6 \mathrm{a}$ & $1.2 \pm 0.2 \mathrm{~b}$ & $2.7 \pm 1.2 \mathrm{a}$ \\
Native & $93.8 \pm 10.8 \mathrm{a}$ & $2.2 \pm 1.6 \mathrm{a}$ & $34.2 \pm 2.0 \mathrm{a}$ & $2.1 \pm 0.5 \mathrm{a}$ & $2.7 \pm 0.6 \mathrm{a}$ \\
UFLA05 & $52.2 \pm 4.2 \mathrm{~b}$ & $0.7 \pm 7.8 \mathrm{~b}$ & $42.5 \pm 7.8 \mathrm{a}$ & $0.4 \pm 0.0 \mathrm{~d}$ & $1.3 \pm 1.2 \mathrm{a}$ \\
UFLA351 & $74.7 \pm 1.0 \mathrm{a}$ & $1.9 \pm 1.9 \mathrm{a}$ & $37.2 \pm 1.9 \mathrm{a}$ & $0.8 \pm 0.2 \mathrm{c}$ & $2.0 \pm 1.0 \mathrm{a}$ \\
UFLA372 & $85.2 \pm 13.3 \mathrm{a}$ & $2.6 \pm 3.1 \mathrm{a}$ & $37.7 \pm 3.1 \mathrm{a}$ & $1.2 \pm 0.1 \mathrm{~b}$ & $2.0 \pm 1.0 \mathrm{a}$ \\
UFLA401 & $81.2 \pm 5.4 \mathrm{a}$ & $2.4 \pm 0.1 \mathrm{a}$ & $38.3 \pm 8.1 \mathrm{a}$ & $1.3 \pm 0.1 \mathrm{~b}$ & $2.7 \pm 0.6 \mathrm{a}$ \\
\hline
\end{tabular}

${ }^{1}$ Treatment: Control - without inoculation with arbuscular mycorrhizal fungi; Native - native microbial inoculant; UFLA05 - G. albida; UFLA351 - R. clarum; UFLA372 - C. etunicatum e UFLA401 - A. morrowiae; and ${ }^{2}$ Averages followed by the same letter in the column do not differ statistically from each other a $5 \%$ probability by the Scott-Knott test. 
In general, it is observed that the positive correlation of the mycorrhizal colonization of the vetiver grass with UFLA372 and the dark septate endophytic fungi did not guarantee the increase of dry matter of the shoot and the root (Tables 2 to 4 ). Further, the mycorrhizal colonization of vetiver grass and the presence of dark septate endophytic fungi did not stimulate tiller formation (Table 4).

The mycorrhizal colonization of the vetiver grass with the native inoculum favored only the shoot dry matter. However, the use of UFLA351 isolate resulted in a negative correlation between colonization and root length. A negative correlation between colonization with root dry matter with UFLA05 was also observed. Similarly, the presence of the dark septate endophytic fungi was positively correlated only with the shoot dry matter of the vetiver grass inoculated with UFLA401, but showed a negative correlation between the dark septate endophytic fungi and the root length in the treatment with UFLA351. The presence of dark septate endophytic fungi did not influence root dry matter in any of the treatments, which can be inferred from the lack of correlation between these parameters (Table 4).

Table 4. Correlation coefficient (r) between mycorrhizal colonization (MC), dark septate endophytic fungi (DSEND), root length (RL), shoot dry matter (SDM), root dry matter (RDM), and number of tillers (NT) obtained in the vetiver grass cultivated with native microbial inoculant and isolated UFLAs.

\begin{tabular}{lcccccc}
\hline \multirow{2}{*}{ Parameters } & \multicolumn{6}{c}{ Correlaciton coefficicent (r), by treatment } \\
\cline { 2 - 7 } & Controle & Nativo & UFLA05 & UFLA351 & UFLA372 & UFLA401 \\
\hline MC x SDM & - & $0.979^{* 2}$ & - & - & - & - \\
MC x RL & - & - & - & $-0.991^{* *}$ & - & - \\
MC x RDM & - & - & $-0.954^{*}$ & - & - & - \\
\hline DSEND x SDM & - & - & - & - & - & $0.999^{* *}$ \\
DSEND x RL & - & - & - & $-0.979^{*}$ & - & - \\
DSEND x RDM & - & - & - & - & - & - \\
\hline NT x MC & - & $-0.986^{*}$ & - & - & - & - \\
NT x DSEND & - & - & - & - & - & $-0.999^{* *}$ \\
\hline
\end{tabular}

${ }^{1}$ Treatment: Control - without inoculation with arbuscular mycorrhizal fungi; Native - native microbial inoculant; UFLA05 - G. albida; UFLA351 - R. clarum; UFLA372 - C. etunicatum e UFLA401 - A. morrowiae; and $^{2}$ ns $=$ not significant; $*=$ significant at $5 \%$ probability $(0.1 \leq \mathrm{p}<0.5)$ and $* *=$ significant at $1 \%$ probability $(\mathrm{p}<0.1)$.

The number of tillers was not correlated with mycorrhizal colonization and with the presence of dark septate endophytic fungi in any of the treatments except for native microbial inoculant that presented a negative correlation with the colonization and in the treatment with UFLA401 that was negatively correlated with the presence of endophytic fungi (Table 4).

Cavagnaro et al. (2014) also observed that the interaction between the mycorrhizal arbuscular fungi and Poaceae members did not influence the number of tillers of Paspalum dilatatum, but resulted in a higher tiller biomass in relation to the control, which may contribute to survival under field conditions. The biomass of the tillers, however, was not evaluated in this study.

Considering that the tiller used in this bioassay showed a $10.2 \%$ mycorrhizal colonization by native arbuscular mycorrhizal fungi, there was probably a negative interaction between all the tested UFLAs and the native microbiota (mycorrhizal and endophytic) in the treatments, especially when considering plant height and root volume (Figure 2).

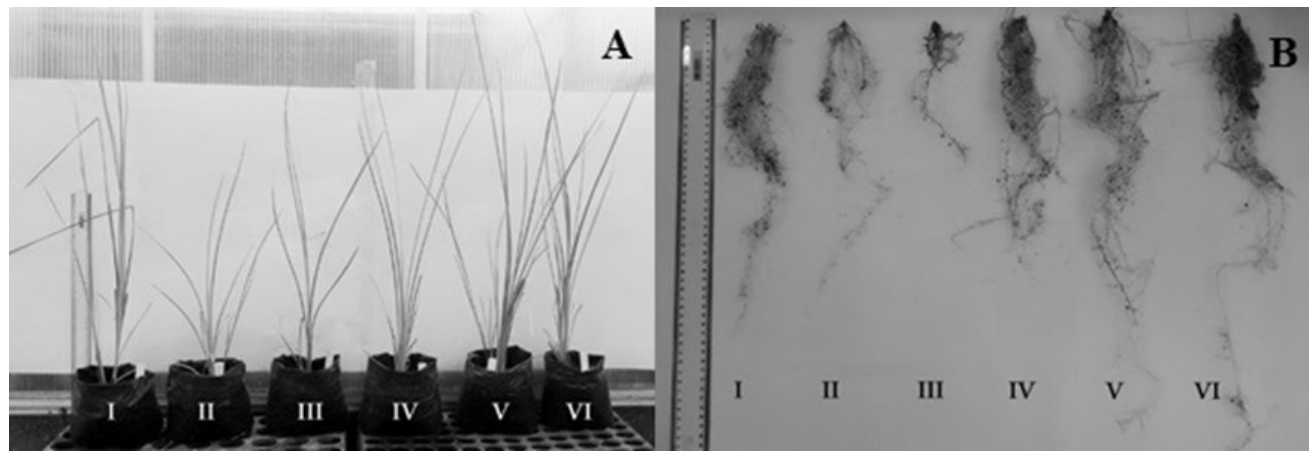

Figure 2. Shoot (A) and root (B) of the vetiver grass growth cultivated with native microbial inoculant and UFLAs isolated after 100 days of inoculation*.

*Treatment: I = UFLA401 - A. morrowiae; II = UFLA05 - G. albida $; \mathrm{III}=\mathrm{UFLA351}-R$. clarum; IV = UFLA372 - $C$. etunicatum; $\mathrm{V}=\mathrm{Control}$ - without inoculation with arbuscular mycorrhizal fungi; and $\mathrm{VI}=\mathrm{Native}$ - native microbial inoculant. 
According to Machineski, Balota and Souza (2011), plants that present mycorrhizal dependence values between 25 and $50 \%$ are considered to be responsive to mycorrhizal inoculation, but with moderate dependence. In this context, vetiver grass was responsive only in the treatment with native microbial inoculant when considering root dry matter (RDM), which increased by $40.3 \%$ in relation to the control (Figure 3).

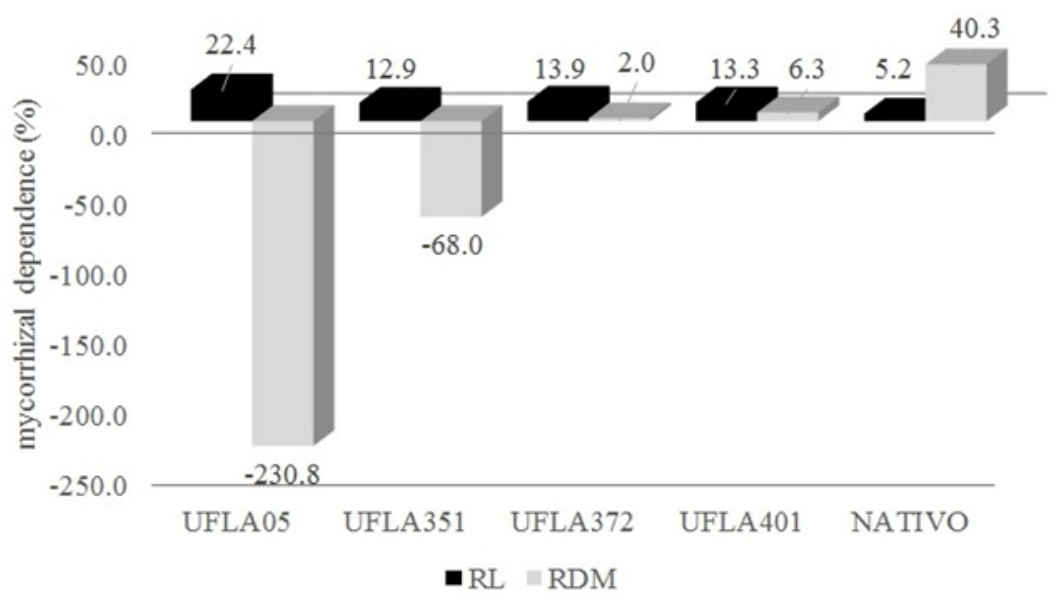

Figure 3. Mycorrhizal dependence values in the root length (RL) and root dry matter (RDM) of the vetiver grass cultivated with native and arbuscular mycorrhizal fungi, after 100 days of inoculation*.

*Treatment: Control - without inoculation with arbuscular mycorrhizal fungi; Native - native microbial inoculant; UFLA05 - G. albida; UFLA351 - R. clarum; UFLA372 - C. etunicatum e UFLA401 - A. morrowiae

Comparatively, Cavagnaro et al. (2014) observed that the interaction between mycorrhizal arbuscular fungi and plants of the family Poaceae such as Panicum coloratum, that are found in tropical climates, resulted in an increase of 202 to $206 \%$ in the dry matter, while Paspalum dilatatum presented $98 \%$ more biomass in relation to the control. However, the mycorrhizal colonization of vetiver grass can stimulate the formation of fine roots and, consequently, favor the increase of the root biomass, which are important in the absorption of water and nutrients for the plants to produce the photoassimilates to be transferred to mycorrhizal fungi and to propagation structures, such as tillers.

According to Machado et al. (2015), the thin roots of vetiver grass showed high shear strength, which contributed to a reduction in erosion processes. Thus, the control of erosive processes by plants, such as vetiver, should be investigated because the presence of arbuscular mycorrhizal fungi can influence the root biomass and consequently favor soil conservation.

In general, the native microbial inoculant was distinguished in relation to the tested UFLA isolates, but it must be considered that in the native microbial inoculant, a variety of mycorrhizal fungi can be used to influence the response of the vetiver grass to the arbuscular mycorrhizal fungi tested. The increase in the root dry matter of the vetiver grass with native microbial inoculum composed of mycorrhizal fungi and endophytic fungi may be correlated to the increase in the area of water and nutrient uptake by symbiotic microorganisms. Thus, this behavior may contribute to the survival of vetiver grass under adverse conditions, such as in the field.

\section{CONCLUSIONS}

The effect of the inoculation of the arbuscular mycorrhizal isolates was influenced by the presence of native mycorrhizal fungi and the dark septate endophytic fungi.

The association of vetiver grass with dark septate endophytic fungi is positively correlated with mycorrhizal colonization by UFLA372, but does not guarantee the increase in plant biomass.

The mycorrhizal colonization of the vetiver grass is of the vesicular type, but the formation of the arbuscules of the fungal isolates tested can be correlated with the fungi-plant-environment interaction, mainly considering the rainy and dry periods of the year.

Vetiver grass is responsive to the native microbial inoculant, as it favors the increment of dry root matter.

\section{REFERENCES}

ALVES, J. C. et al. Absorção e distribuição de chumbo em plantas de vetiver, jureminha e algaroba. Revista Brasileira de Ciências do Solo, Viçosa, v. 32, n. 3, p. 1329-1336, 2008.

BARBOSA, M. C. R.; LIMA, H. M. Resistência ao cisalhamento de solos e taludes vegetados com 
capim vetiver. Revista Brasileira de Ciências do Solo, Viçosa, v. 37, n. 1, p. 113-120, 2013.

CAPORALE, A. G. et al. Effect of arbuscular mycorrhizal fungi (Glomus spp.) on growth and arsenic uptake of vetiver grass (Chrysopogon zizanioides L.) from contaminated soil and water system. Journal of Soil Science and Plant Nutrition, Temuco, v. 14, n. 4, p. 955-972, 2014.

CARNEIRO, M. A. C. et. al. Micorriza arbuscular em espécies arbóreas e arbustivas de ocorrência no sudeste do Brasil. Cerne, Lavras, v. 4, n. 1, p. 129145, 1998.

CAVAGNARO, R. A. et al. Screening of biomass production of cultivated forage grasses in response to mycorrhizal symbiosis under nutritional deficit conditions. Japanese Society of Grassland Science, Tochigi, v. 60 , n. 1, p. 178-184, 2014

DUTTA, D. et al. Endophytes: Exploitation as a tool in plant protection. Brazilian Archives of Biology and Technology, Curitiba, v. 57, n. 5. p. 621-629, 2014.

GARCÍA, I. V.; MENDOZA, R. E. Relationships among soil properties, plant nutrition and arbuscular mycorrhizal fungi-plant symbioses in a temperate grassland along hydrologic, saline and sodic gradients. FEMS Microbiology Ecology, Amsterdam, v. 63, n. 3, p. 359-371, 2008.

GERDEMANN, J. W.; NICOLSON, T. H. Spores of mycorrhizal endogone species extracted from soil by wet-sieving and decanting. Transactions of British Mycological Society, Cambridge, v. 46, n. 2, p. 235 244, 1963.

GIOVANNETTI, M.; MOSSE, B. An evaluation of techniques for measuring vesicular arbuscular mycorrhizal infection in roots. New Phytologist, Cambridge, v. 84, n. 3, p. 489-500, 1980.

GRAHAM, J. H. et al. Development of external hyphae by different isolates of mycorrhizal Glomus spp. in relation to root colonization and growth of Troyer citrange. New Phytologist, Cambridge, v. 91, n. 1, p. 183-189, 1982.

HOLANDA, F. S. R. et al. Crescimento inicial de espécies florestais na recomposição da mata ciliar em taludes submetidos à técnica da bioengenharia de solo. Ciência Florestal, Santa Maria, v. 20, n. 1, p. 157-166, 2010.

KARIMI, N.; BAHARLOUEI, J.; SABZALIAN. M. R. Effect of arbuscular mycorrhizal fungi on growth parameters of vetiver grass in a cd-contaminated soil. In: INTERNACIONAL CONFERENCE ON
NEW IDEAS IN AGRICULTURE, 1, 2014, Isfahan. Anais... Isfahan: Islamic Azad University Khorasgan Branch, 2014, p. 1.

LIMA, R. L. F. A.; SALCEDO, I. H.; FRAGA, V. S. Propágulos de fungos micorrízicos arbusculares em solos deficientes em fósforo sob diferentes usos, da região semi-árida no nordeste do Brasil. Revista Brasileira de Ciência do Solo, Viçosa, v. 31, n. 2, p. 257-268, 2007.

LOPES, E. S.; SIQUEIRA, J.; ZAMBOLIM, L. Características das Micorrizas VesículoArbusculares e seus Efeitos no Crescimento das Plantas. Revista Brasileira de Ciência do Solo, Viçosa, v. 7, n. 1, p. 1-19, 1983.

MACHADO, L. et al. Contribuição do sistema radicular do capim-vetiver para estabilização do talude do Rio São Francisco. Semina: Ciências Agrárias, Londrina, v. 36, n. 4, p. 2453-2464, 2015.

MACHINESKI, O.; BALOTA, E. L.; SOUZA, J. R. P. Resposta da mamoneira a fungos micorrízicos arbusculares e a níveis de fósforo. Semina: Ciências Agrárias, Londrina, v. 32, n. 4, p. 1855-1862, 2011.

MIRANDA, J. C. C. Cerrado: Micorriza Arbuscular-ocorrência e manejo. 1. ed. Planaltina, GO: Embrapa Cerrados, 2008. 169 p.

MOREIRA, F. M. S.; SIQUEIRA, J. O. Micorrizas. In: MOREIRA, F. M. S.; SIQUEIRA, J. O. (Eds.). Microbiologia e bioquímica do solo. Lavras: UFLA, 2006. v. 2, cap. 10, p. 543-661.

MOREIRA, M.; BARRETTA, D.; CARDOSO, E. J. B. N. Doses de fósforo determinam prevalência de fungos micorrízicos arbusculares em Araucaria angustifolia. Ciência Florestal, Santa Maria, v. 22, n. 4, p. 813-820, 2012.

RAMOS, M. L. G. et al. Diversidade de fungos micorrízicos e colonização radicular, em forrageiras solteiras e em consórcio com Milho. Bioscience Journal, Uberlândia, v. 28, n. 2, p. 235-244, 2012.

RIBEIRO, K. G. et al. Isolamento, armazenamento e determinação da colonização por fungos "dark septate" a partir de plantas de arroz. Revista Agro@ambiente, Boa Vista, v. 5, n. 2, p. 97-105, 2011.

RUBIN, J. G. K. R.; STÜRMER, S. L. Potencial de inóculo micorrízico e importância do comprimento do micélio para agregação de solos de ambiente fluvial. Revista Brasileira de Ciência do Solo, Viçosa, v. 39, n. 1, p. 59-68, 2015.

SANTOS, E. A. et al. Occurrence of symbiotic fungi 
and rhizospheric phosphate solubilization in weeds. Acta Scientiarum. Agronomy, Maringá, v. 35, n. 1, p. 49-55, 2013.

SANTOS, T. T.; VARAVALlO, M. A. Aplicação de micro-organismos endofíticos na agricultura e na produção de substâncias de interesse econômico. Semina: Ciências Biológicas e da Saúde, Londrina, v. 32, n. 2, p. 199-212, 2011.

SOUSA, C. S. et al. Glomalina: características, produção, limitações e contribuições nos solos. Semina: Ciências Agrárias, Londrina, v. 33, Sup., p. 3033-3044, 2012.

STÜRMER, S. L.; SIQUEIRA, J. O. Diversidade de Fungos Micorrízicos Arbusculares em Ecossistemas Brasileiros. In: MOREIRA, F. M. S.; SIQUEIRA, J. O.; BRUSSAARD, L. (Eds.). Biodiversidade do solo em Ecossistemas Brasileiros. Lavras: UFLA, 2008. v. 1 , cap. 16 , p. $537-583$.

TRUONG, P.; VAN, T. T.; PINNERS, E. Sistema de aplicação do vetiver: manual de referência técnica. 2. ed. Recife: PE: REDE INTERNACIONAL DE VETIVER, 2008. 116 p.

VAN DER HEIJDEN, M. G. A. et al. Mycorrhizal ecology and evolution: the past, the present, and the future. New Phytologist, Cambridge, v. 205, n. 4, p. 1406-1423, 2015.

YAN, J. F. et al. Do endophytic fungi grow throught their hosts systemically? Fungal ecology, Manchester, v. 13, n. 1, p. 53-59, 2015. 